\title{
POSLEDICE DEINDUSTRIJALIZACIJE I EKONOMSKI EFEKTI REINDUSTRIJALIZACIJE NA PRIMERU ZEMALJA ZAPADNOG BALKANA
}

\begin{abstract}
Rezime
Reindustrijalizacija predstavlja proces obnove industrijske proizvodnje sa ciljem povećanja učešća industrije u stvaranju ukupnog BDP-a. U zemljama zapadnog Balkana, reindustrijalizacija je prepoznata kao nužan proces koji ima za cilj povećanje zaposlenosti, unapređenje strukture njihovog izvoza i pozicije u međunarodnim ekonomskim odnosima. Reindustrijalizacija je, kao koncept ozdravljenja privrede, determinisana samom suštinom procesa tranzicije i reformi koje su taj proces obeležile. Drugim rečima, reindustrijalizacija je "odgovor" na negativne posledice deindustrijalizacije i tercijarizacije privrede. Primena ova dva koncepta na privrede zemalja zapadnog Balkana, zahvaljujući njihovom ekonomskom nasleđu i geoekonomskom položaju nije dala pozitivne efekte kao u nekim drugim zemljama u tranziciji. U ovom radu, autorka bavi analizom dosadašnjih efekata procesa reindustrijalizacije u zemljama zapadnog Balkana, sa posebnim osvrtom na potencijale i moguće pravce razvoja njihovih industrija u budućnosti
\end{abstract}

Ključne reči: deindustrjalizacija, reindustrijalizacija, ekonomija, zapadni Balkan.

\section{UVOD}

Ekonomski razvoj grupe zemalja zapadnog Balkana kojoj pripadaju Albanija, Bosna i Hercegovina, Crna Gora, Srbija i Severna Makedonija, se već pune tri decenije odvija pod okriljem i po pravilima procesa tranzicije. Društveno-politički i ekonomski ambijent koji je u ovim zemljama kreiran u pred-tranzicionom periodu uslovio je razumevanje i prihvatanje osnovnih postulata procesa tranzicije, kao i dinamiku realizacije tog procesa. Osim internim društvenim i ekonomskim faktorima, tok tranzicije je u prvim godinama njenog sprovođenja bio determinisan i političkim događajima koji su se odvijali na prostoru tih zemalja i procesima koji su se odvijali na području zapadne Evrope. Antagonizam tih procesa: na jednoj strani povezivanja i saradnje u Evropi i na drugoj fragmentacije i konflikata na zapadnom Balkanu, odredio je i ekonomski položaj novih tranzicionih zemalja u Evropi i definisao odnose Evropske unije prema njima kao potencijalnim članicama te integracije. Tranzicija ove grupe zemalja u ekonomskom smislu podrazumevala je prelazak na tržišni način privređivanja čiji su osnovni postulati bili: privatizacija, deindustrijalizacija i liberalizacija ekonomskih tokova. Deindustrijalizacija, kao novi razvojni koncept koji

1 ibozicmiljkovic@gmail.com 
je imao za cilj smanjenje učešća industrije, a povećanje učešća sektora usluga u privredama ovih zemalja u značajnoj meri je doprineo urušavanju njihovih privrednih sistema. Problemi se javljaju već u prvim godinama tranzicije. Drastičan pad industrijske proizvodnje, smanjenje obima izvoza industrijskih proizvoda i pad konkurentnosti industrijske proizvodnje na međunarodnom tržištu doprineli su sužavanju izvoznog tržišta, odnosno broj zemalja - izvoznih destinacija je značajno redukovan. Treba napomenuti da je industrija, u drugoj polovini XX veka u gotovo svim zemljama zapadnog Balkana predstavljala motor privrednog razvoja. Izvozom industrijskih proizvoda ove zemlje su ostvarivale značajne devizne prilive, a mnoge od njih su na svetskom tržištu bile prepoznate po kvalitetu svojih brendova. Sektor industrije je, kao najrazvijeniji, zapošljavao najveći deo radno sposobnog stanovništva. Devastacijom industrijskih kapaciteta, veliki broj zaposlenih u industriji ostaje bez posla što sa sobom nosi niz posledica ekonomsko-socijalne prirode, pa se može reći da je ekonomska kriza koja je u prvim godinama tranzicije nastala u zemljama zapadnog Balkana, generisana urušavanjem industrije kao vodeće privredne delatnosti, predstavljala okidač za mnogo širu društvenu krizu koja traje dugo I čiji je ishod neizvestan.

Politika reindustrijalizacije u zemljama zapadnog Balkana sprovedena je implementacijom modela koji su se pokazali efikasnim u procesu tranzicije zemalja centralne i istočne Evrope. Strategija oživljavanja industrijske proizvodnje zasniva se na povećanju učešća stranog kapitala u domaćoj industriji i razvoju sektora niskih I srednje niskih tehnologija. Takva razvojna strategija ne obezbeđuje zemljama zapadnog Balkana strukturu izvoza kakvu imaju ekonomski razvijene zemlje niti konkurentnost na međunarodnom tržištu koja bi na duži rok obezbedila odgovarajuću dinamiku izvoza I stabilnost deviznih prihoda po tom osnovu.

\section{Kratak osvrt na istorijat industrijske proizvodnje u periodu pre tranzicije}

Tokom XIX i u XX veku, proces industrijalizacije je postao obeležje privreda razvijenih zemalja. U osnovi tog procesa bila su velika naučna i tehnološka otkrića, koja su generisala i usmeravala proces privrednog razvoja, određujući njegovu dinamiku i strukturu. Ubrzan razvoj svetske privrede praćen odgovarajućim tehničko-tehnološkim napretkom, uslovio je diversifikaciju njene proizvodne strukture, porast produktivnosti i intenzivniju međunarodnu trgovinu. U drugoj polovini XX veka, po završetku Drugog svetskog rata, proces industrijalizacije zahvata i socijalističke zemlje centralne i istočne Evrope kojima su geografski pripadale i današnje zemlje zapadnog Balkana. Sve do početka '90-tih godina industrija je bila vodeća privredna delatnost, široko prihvaćen metod privrednog razvoja i važan deo strategije modernizacija njihovih ekonomija. Industrijska proizvodnja je u ovim zemljama na godišnjem nivou rasla brže od stopa koje su beležile razvijene kapitalističke zemlje, pa čak brže i od svetskog proseka. 
Tabela 1

Dinamika rasta industrijske proizvodnje u svetu i po grupama zemalja u periodu industrijalizacije: uporedni prikaz

\begin{tabular}{|l|c|c|c|c|}
\hline Period & Svet & $\begin{array}{c}\text { Socijalističke } \\
\text { zemlje }\end{array}$ & $\begin{array}{c}\text { Razvijene } \\
\text { kapitalističke } \\
\text { zemlje }\end{array}$ & Zemlje u razvoju \\
\hline $1961-1985$ & 5,1 & 6,9 & 3,9 & 4,6 \\
\hline $1971-1985$ & 4,2 & 6,6 & 2,7 & 3,1 \\
\hline $1981-1985$ & 3,2 & 5,5 & 1,8 & $-0,5$ \\
\hline
\end{tabular}

Izvor: Vukmirica, 1988: 58.

Proces industrijalizacije zemalja koje danas pripadaju subregionu zapadnog Balkana (sa izuzetkom Albanije), u periodu pre tranzicije, moguće je pratiti imajući u vidu parametre i pokazatelje koji se u ovoj oblasti odnose na bivšu Jugoslaviju u čijem su se sastavu u to vreme nalazile. Prvi pokušaj te zajedničke države da model industrijalizacije podigne na viši nivo, dajući pri tome značaj modernizaciji bio je 1965. godine donošenjem mera Privredne reforme (Latifić, 1997: 13). Među brojnim ciljevima sadržanim $\mathrm{u}$ tom dokumentu izdvajala su se tri: uključivanje u međunarodnu podelu rada, odnosno, izlazak na svetsko tržište, decentralizacija upravljanja i zamena ekstenzivnog modela razvoja intenzivnim, odnosno prelazak sa kvantitativnog na kvalitativni rast (Savić, 2010: 268). Uporedo sa napretkom procesa industrjalizacije, razvojem industrije i diversifikacijom industrijskih sektora i grana, menjala se i struktura proizvodnje I izvoza. U toj strukturi su sve značajnije mesto zauzimali proizvodi prerađivačke industrije višeg stepena finalizacije, neki sofisticirani industrijski proizvodi kao što su kompjuteri, mikroprocesori, medicinski uređaji, pa čak i automobili. Osim toga, sektor industrije je zapošljavao najveći deo radno sposobnog stanovništva. Zahvaljujući razvijenom sektoru industrije stope nezaposlenosti su tokom druge polovine XX veka, sve do početka '90-tih godina bile minimalne. Vladajući oblik svojine nad sredstvima za proizvodnju bila je društvena svojina, dok privatna svojina nad sredstvima za proizvodnju nije postojala. Radnička klasa činila je okosnicu srednjeg sloja stanovništva, a njeno ekonomsko obeležje činio je solidan životni standard i visok stepen socijalne sigurnosti čije su odrednice između ostalog, bile besplatno školovanje, besplatna zdravstvena zaštita, državna regulacija stanovanja - dodeljivanjem društvenih stanova na korišćenje i sl. (Božić, 1996:17).

Finansiranje razvoja industrije u predtranzicionom periodu odvijalo se sredstvima domaće akumulacije i investicija. Struktura tih sredstava bila je podeljena u tri velike grupe: bespovratna sredstva, usmerena sredstva štednje i obavezno udružena sredstva (Čobeljić, 1978: 40). Bespovratna sredstva činila su 36\% ukupnih investicionih sredstava I njihovu strukturu činili su budžetski prihodi (posebni i dopunski porezi iz zarada građana, deo naknade iz cene tečnih goriva, porezi na promet tečnih goriva, deo poreza ostvarenih na nivou republike i sl.). Usmerena sredstva štednje 
stanovništva kod banaka činila su 23\% ukupnih investicionih sredstava, dok su obavezno udružena sredstva činila preostalih $41 \%$ investicionih sredstava (Čobeljić, 1978: 41). Ova poslednja kategorija sredstava podrazumevala je obavezna izdvajanja privrede i stanovništva za razvoj onih industrijskih grana u kojima je tadašnja Jugoslavija ostvarivala najveće komparativne prednosti: prerađivačku industriju, sektor energetike i modernizaciju poljoprivredne proizvodnje. S obzirom na izuzetno povoljne klimatske i geomorfološke uslove za razvoj poljoprivrede, posebna pažnja je poklanjana razvoju prehrambene industrije. Modernizacija infrastrukture, komunalne privrede i izgradnja hidrocentrala za proizvodnju električne energije realizovane su uglavnom zaduživanjem kod međunarodnih finansijskih institucija (World bank, 1979: 4).

Fokus na razvoju i modernizaciji industrije za kratko vreme je pokazao pozitivne efekte na ukupan privredni rast i razvoj. U periodu od 1952-64 godine prosečna stopa rasta BDP-a u bivšoj Jugoslaviji iznosila je $8,6 \%$, dok je u periodu 1964-78 godine zabeleženo 5,6\%. U istim periodima, udeo dodate vrednosti industrije u BDP-u iznosio je taksativno 12,7\% i 7,1\%, dok je udeo dodate vrednosti poljoprivrede u BDP-u iznosio 4,5\% odnosno 1,7\% (Savezni zavod za statistiku, 1986: 181). Dominantno učešće industrijskih proizvoda u strukturi proizvodnje i posebno, u strukturi izvoza, obezbeđivalo je, po kriterijumima Svetske Banke, tadašnjoj Jugoslaviji status srednje razvijene zemlje, svrstavajući je u grupu zemalja sa višim srednjim dohotkom (World bank). Samo nekoliko decenija kasnije, zahvaljujući tranzicionim reformama, zemlje zapadnog Balkana kao samostalne države, neće imati takav status.

Za razliku od bivše Jugoslavije u kojoj je druga polovina XX veka ostala zabeležena kao period ekonomskog prosperiteta, Albanija je, u istom periodu, u pogledu ekonomskog razvoja imala sve odlike zatvorene, autarkične privrede. Tempo njenog ekonomskog razvoja bio je vrlo spor pa je i njena ekonomska struktura ostala nepromenjena sa veoma visokim učešćem poljoprivrede i ostalih delatnosti iz primarnog sektora privrede (Božić Miljković, 2018: 40). Tek pred kraj XX veka dolazi do postepenog otvaranja Albanije prema Evropi i prihvatanja novih modela ekonomskog razvoja. Tada Albanija, kao i nove samostalne države sa prostora bivše Jugoslavije kreće na put tranzicije, međutim, bez velikih uspeha na ekonomskom planu.

\section{Tranzicija zemalja zapadnog Balkana i proces deindustrijalizacije}

Industrija zemalja zapadnog Balkana je, u prvim godinama tranzicije, bila izložena dramatičnim promenama njenih dotadašnjih uslova poslovanja i pravila funkcionisanja. Nagla privatizacija industrijskih preduzeća, uz primene brojnih preporuka međunarodnih institucija za brzo prevazilaženje procesa tranzicije, dovele su za kratko vreme do pada privredne aktivnosti, pada svih vidova potrošnje i pada tražnje za industrijskim proizvodima (Kovačević, 2011). Način na koji je sprovedena tranzicija, naročito u prvim godinama tog procesa, imao je višestruke negativne efekte na dalji razvoj industrije u zemljama zapadnog Balkana i velike posledice na strukturu, obim i dinamiku njihovog izvoza. To je imalo implikacija i na njihov 
položaj u međunarodnim ekonomskim odnosima i determinisalo odnos međunarodnih finansijskih i drugih institucija prema njima.

Prihvatanjem procesa deindustrijalizacije kao integralnog dela tranzicije, došlo je do drastičnog pada industrijske proizvodnje u gotovo svim granama i sektorima. Industrija je izgubila stabilan oslonac $u$ domaćem tržištu koji je imala gotovo pola veka. Značajan pad aktivnosti u delatnostima poput saobraćaja, građevinarstva, poljoprivrede, turizma tokom '90-tih godina uslovio je i pad tražnje za industrijskim proizvodima u ovim sektorima, što se negativno odrazilo na obim industrijske proizvodnje. Učešće industrije u GDP 1983. godine iznosilo je 43\%, 1993. godine $23 \%$, 1996. godine $15,5 \%$, a 2002. godine svega 10,5\% (UNCTAD, Handbook of Statistics).

Period deindustrijalizacije uzemljama zapadnog Balkana, na svetskom tržištu je obeležio trend rasta tražnje za sirovinama, poluproizvodima I gotovim proizvodima nižeg stepena finalizacije. U izvozu tih proizvoda, zemlje zapadnog Balkana prepoznaju novu razvojnu šansu, koja u datim uslovima stimuliše ekonomski rast, ali na duži rok menja njihov status $u$ međunarodnim ekonomskim odnosima i ima negativne efekte na privredni razvoj svake od njih pojedinačno. Struktura izvoza ovih zemalja, iako su one $\mathrm{u}$ procesu tranzicije, odgovara strukturi izvoza kakvom se odlikuju zemlje u razvoju, odnosno zemlje koje su u međunarodnoj trgovini pozicionirane kao izvoznice sirovina i primarnih proizvoda. Takva struktura izvoza u kojoj se svetskom tržištu plasiraju jeftine sirovine, a sa druge strane sa istog tog tržišta se uvoze skupi finalni proizvodi, ima duboke i trajne konsekvence na platni bilans. Deficit spoljnotrgovinskog bilansa je još jedna zajednička odlika ove grupe zemalja u tranziciji, a podaci dati u narednom grafiku potvrđuju da taj deficit ima rastući trend i hroničan tok.

Grafik 1

Spoljnotrgovinski bilans zemalja zapadnog Balkana u periodu od 2001. do 2019. godine (u mil USD)

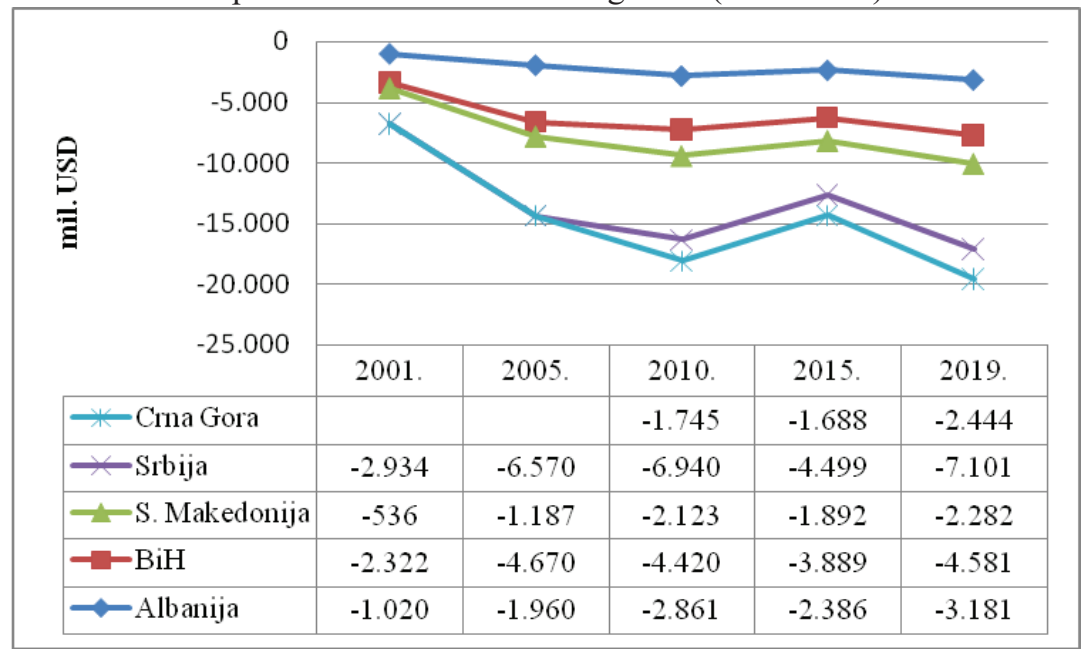

Izvor. UNCTAD Handbook of Statistics (http://unctadstat.unctad.org/wds/TableViewer/ tableView.aspx), pristupljeno novembra 2020. 
Trendovi u kretanju spoljnotrgovinskog deficita u prikazanom vremenskom periodu rezultat su i posledica upravo procesa deindustrijalizacije u zemljama zapadnog Balkana. Pad produktivnosti u sektoru industrije, gubitak domaćeg tržišta, kao i odsustvo finansijske podrške od strane države kroz subvencije i sredstva iz budžeta, doprineli su drastičnom smanjenju konkurentnosti industrijskih proizvoda koji vode poreklo iz zemalja zapadnog Balkana. Od svih pomenutih izazova, industrijska preduzeća iz ovih zemalja bila su najteže pogođena činjenicom da sistem tržišnog privređivanja ne prepoznaje državu u funkciji regulatora tržišnih odnosa (Božić, 2005: 430). Sigurne subvencije od strane države, neuslovljene rezultatima poslovanja postale su deo ekonomske istorije ovih zemalja. Proces tranzicije podrazumevao je njihov izlazak na tržište i samostalnu borbu sa konkurencijom koja na njemu vlada. U toj tržišnoj utakmici došle su do izražaja mnoge slabosti industrijskih preduzeća iz zemalja zapadnog Balkana. U osnovi tih slabosti bilo je naglo napuštanje starog i nekritički odnos prema postulatima na kojima se zasniva novi sistem privređivanja, posebno prema deindustrijalizaciji. Aktivnosti sprovođene na tom planu, uticale su na smanjenje konkurentnosti izvoza ovih zemalja, što je imalo određene posledice na njihov ekonomski razvoj.

Smanjenju konkurentnosti doprineo je i fenomen zakasnele tranzicije, odnosno činjenica da su prvu deceniju tog procesa zemlje zapadnog Balkana posvetile više političkim pitanjima, zanemarujući pritom ona koja se tiču ekonomskog razvoja i modernizacije privrede. Kao formalni početak procesa tranzicije u ovoj grupi zemalja smatra se kraj '80-tih godina prošlog veka, ali do političke stabilizacije, prihvatanja i primene tranzicionih reformi u većini njih dolazi tek početkom ovog veka (Sanfey \& Milatović, 2019: 41) Zakasnela tranzicija uslovila je, između ostalih problema i tehnološku inferiornost ove grupe zemalja u poređenju sa razvijenim zemljama Evrope ili bivšim socijalističkim zemljama koje su brže i bezbolnije prošle kroz proces tranzicije. Razvoj nauke, tehnologija i znanja podrazumeva resurse i ulaganja. U slučaju zemalja zapadnog Balkana, na obe strane postoje značajna ograničenja, ali postoji i potreba za aktivnim odnosom prema tehnološkoj modernizaciji koja je generator razvoja industrije i ekonomskog prosperiteta.

Jedno od obeležja procesa tranzicije, a ujedno smisao i odraz deindustrijalizacije, jeste I rast učešća sektora usluga u proizvodnji I zaposlenosti uz smanjenje učešća sektora industrije. Ovakva deindustrijalizacija je fenomen koji postoji u globalnoj ekonomiji i odlika je zrelih industrijskih društava i razvijenih zemalja (Przywara, 2017: 442). U zemljama zapadnog Balkana, taj proces je implementiran naglo i nekritički sa nedovoljno artikulisanom idejom i vizijom da se na taj način tranzicione privrede približe kapitalističkim tržišnim privredama u kojima takva privredna struktura ima dugu tradiciju. U prilog različitom shvatanju deindustrijalizacije između razvijenih zemalja i zemalja u tranziciji govore podaci da se kod razvijenih zemalja maksimalno učešće industrije u GDP ostvaruje kod nivoa GDP per capita između 3000 i 3500 dolara (Mićić, 2015: 21-22). U Srbiji je, na primer, proces deindustrijalizacije počeo 1990. godine, kada je maksimalno učešće industrije u BDP ostvareno kod nivoa GDP per capita 
od 1450 dolara (Mićić, 2015: 22). Slično je bilo i kod drugih zemalja zapadnog Balkana koje su 1990. godine dostigle sledeće vrednosti GDP per capita: Albanija 639,5 dolara, Bosna i Hercegovina 318 dolara, Makedonija 2.240 dolara (the World Bank).

Tabela 2

Struktura BDP zemalja zapadnog Balkana: udeo poljoprivrede, industrije i usluga

\begin{tabular}{|c|l|c|c|c|c|c|}
\hline & & 2001. & 2005. & 2010. & 2015. & 2019. \\
\hline \multirow{4}{*}{ Albanija } & Poljoprivreda & 22,7 & 18,8 & 18,0 & 19,8 & 18,6 \\
\cline { 2 - 7 } & Industrija & 21,7 & 25,1 & 24,9 & 21,8 & 20,1 \\
\cline { 2 - 7 } & Usluge & 44,9 & 43,6 & 44,0 & 46,3 & 48,6 \\
\hline \multirow{3}{*}{$\mathrm{BiH}$} & Poljoprivreda & 8,9 & 8,3 & 6,8 & 6,2 & 6,1 \\
\cline { 2 - 7 } & Industrija & 19,1 & 21,3 & 22,4 & 22,5 & 23,7 \\
\cline { 2 - 7 } & Usluge & 54,5 & 54,7 & 55,6 & 56,3 & 55,5 \\
\hline \multirow{3}{*}{$\begin{array}{c}\text { S. } \\
\text { Makedonijay }\end{array}$} & Poljoprivreda & 9,7 & 9,7 & 10,1 & 9,7 & 8,8 \\
\cline { 2 - 7 } & Industrija & 20,6 & 20,4 & 21,0 & 23,9 & 23,9 \\
\cline { 2 - 7 } & Usluge & 54,4 & 55,8 & 55,1 & 53,7 & 54,6 \\
\hline \multirow{3}{*}{ Srbija } & Poljoprivreda & 14,7 & 6,7 & 6,6 & 6,7 & 6,2 \\
\cline { 2 - 7 } & Industrija & 32,9 & 29,1 & 25,3 & 25,7 & 25,6 \\
\cline { 2 - 7 } & Usluge & 41,4 & 47,2 & 51,7 & 50,9 & 51,2 \\
\hline \multirow{3}{*}{ Crna Gora } & Poljoprivreda & 10,8 & 8,8 & 7,7 & 8,1 & $\ldots$ \\
\cline { 2 - 7 } & Industrija & 22,3 & 17,3 & 17,1 & 14,4 & $\ldots$ \\
\cline { 2 - 7 } & Usluge & 57,4 & 57,6 & 58,6 & 60,3 & $\ldots$ \\
\hline \hline
\end{tabular}

Izvor: World Bank (https://databank.worldbank.org/source/world-developmentindicators), pristupljeno novembra 2020.

Kao što se na osnovu podataka može videti, u periodu posle 2000. godine, udeo sektora usluga u strukturi GDP se povećava. U strukturi usluga dominiraju finansijske usluge, usluge osiguranja i posredovanja, zatim trgovina i usluge vezane za promet nekretnina. U manjoj meri su zastupljene sofisticirane finansijske usluge, usluge iz oblasti informacionih i informatičkih tehnologija i telekomunikacione usluge koje obezbeđuju veće prihode i pozitivno utiču na izvozne performanse zemlje.

\section{Reindustrijalizacija zemalja zapadnog Balkana i njeni ekonomski efekti}

Iskustva razvijenih zemalja pokazuju da se bez razvoja industrije i tehnološke modernizacije privrede u celini ne mogu postići značajni rezultati u privrednom razvoju. Zato se, u zemljama zapadnog Balkana reindustrijalizacija prepoznaje kao nužan proces kako sa aspekta njihovog samostalnog privrednog razvoja, tako i sa aspekta njihovog uključivanja u regionalne i globalne ekonomske tokove. Oživljavanje industrijske proizvodnje i povećanje učešća te proizvodnje u domaćem proizvodu, pred- 
stavljao je veliki izazov za zemlje zapadnog Balkana. Ovo pre svega, zato što je baza savremene svetske industrije u modernoj tehnologiji koja se veoma intenzivno razvija i obogaćuje novim rešenjima, a sa kojom su zemlje zapadnog Balkana još '90-tih godina prošlog veka izgubile korak (Dall \& Marinković, 2014: 45). Osim toga, razvoj savremene industrije zahteva velika kapitalna ulaganja, na šta ove zemlje nisu spremne. Treće po redu je pitanje potpune ekonomske valorizacije industrijskih proizvoda poreklom iz zapadnobalkanskih zemalja na evropskom i svetskom tržištu, odnosno pitanje njihove konkurentnosti. Uprkos svim ovim problemima, reindustrijalizacija je u svim zemljama zapadnog Balkana prihvaćena kao jedan od veoma važnih I nužnih aspekata privrednog razvoja. Proces revitalizacije industrijskih kapaciteta odvijao se na dva nivoa: tamo gde je to bilo moguće, modernizovane su I proizvodno aktivirane čitave fabrike; tamo gde je proizvodnja bila u velikoj meri devastirana, a proizvodni I tehnološki procesi zastareli, politikom reindustrijalizacije su bili obuhvaćeni zdravi delovi starih industrijskih preduzeća.

Nedostatak domaće akumulacije i tehnološka inferiornost u zemljama zapadnog Balkana uslovili su da se proces reindustrijalizacije odvija uz pomoć i značajno učešće stranih direktnih investicija (Estrin \& Uvalić, 2016: 467). Strane investicije postale su generator privrednog razvoja zemalja zapadnog Balkana, međutim njihov raspored u srtrukturi privrede nije doveo do impresivnog razvoja industrijske proizvodnje, bar ne onih grana koje bi obezbedile dugoročno stabilan ekonomski razvoj. U periodu od 2006. do 2016. godine, u privrede zemalja zapadnog Balkana plasirano je oko 95 milijardi USD stranih direktnih investicija (UNCTAD Handbook of Statistics). Posmatrano po zemljama, raspored plasmana je izvršen na sledeći način:

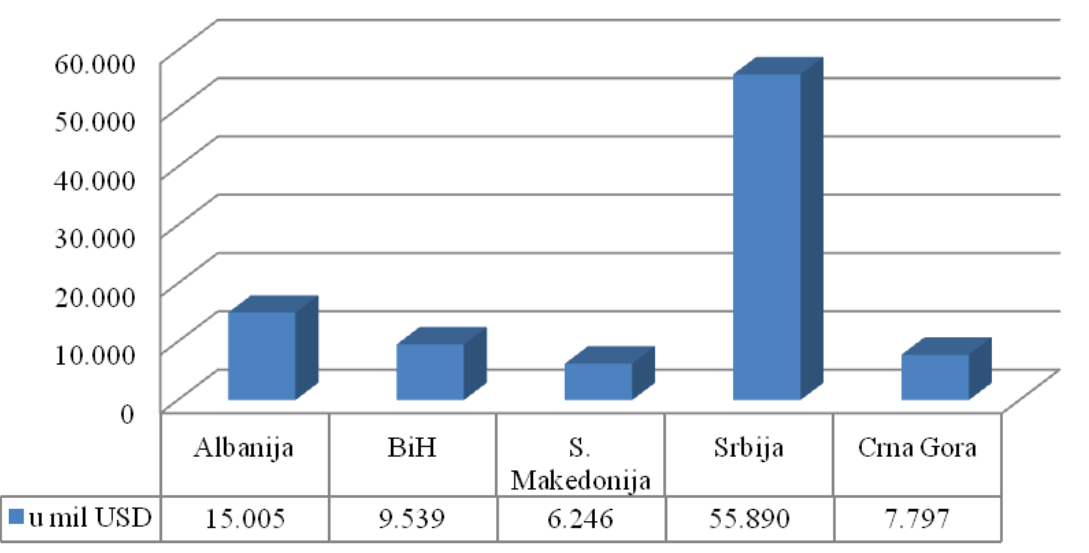

Source: World UNCTAD Handbook of Statistics (http://unctadstat.unctad.org/ $\underline{\text { wds/TableViewer/tableView.aspx }}$ ), pristupljeon novembra 2020.

Među zemljama zapadnog Balkana, po privlačenju stranih direktnih investicija ističe se Srbija. Međutim, i pored velikih brojeva koji se vezuju za priliv stranog kapitala, ozbiljni ekonomski efekti su izostali, odnosno 
Srbija danas nema ni jednu veliku kapitalnu investiciju u razvoj industrije. Slična situacija je i u ostalim zemljama zapadnog Balkana. Veliki deo stranih direktnih investicija plasiran je u sektor usluga: telekomunikacije, finansije i osiguranje, saobraćaj, trgovinu i sl., dok se sektor industrije nalazi na drugom mestu. U okviru tog sektora dominira prerađivačka industrija: proizvodnja hrane, pića i duvana, zatim automobilska industrija, proizvodnja električnih proizvoda i mašina, hemijska industrija i sl (World Bank, 2018: 14). Visoko učešće prerađivačke industrije u ukupnom prilivu stranih investicija u zemljama zapadnog Balkana je, u početnom periodu priliva stranih direktnih investicija bilo u skladu sa njihovim statusom tranzicionih ekonomija i u skladu sa procesom reindustrijalizacije (Savić, 2006: 37). Međutim, kasnije faze reindustrijalizacije podrazumevaju da tehnološki intenzivne industrije, uz angažovanje visoko kvalifikovane i obrazovane radne snage, treba da postanu važan segment industrijske strukture zemalja u tranziciji. To znači da treba intenzivnije ulagati u proizvodnju opreme, postrojenja i uređaja iz domena srednjih i visokih tehnologija (Radošević, 2014:64). Osnovni pravac naučno-tehničkog i tehnološkog razvoja u svetu vezan je za informacione i genetske tehnologije, eksploataciju biomasa, svemirske i laserske tehnologije, bioinženjering, nove izvore energije i nove materijale. U tom smislu, naučni i stručni kadar zemalja zapadnog Balkana mora biti osposobljen da nesmetano može obezbediti transfer odgovarajućih tehnologija, kao i istraživanje i razvoj ovih tehnologija (Đukić, 2014).

Budućnost industrije i društva u celini direktno je uslovljena kvalitetom obrazovnog sistema i stepenom razvoja naučno-istraživačkog rada. Zemlje zapadnog Balkana i u tom smislu zaostaju za razvijenim zemljama Evrope i sveta. Njihova izdvajanja iz budžeta za razvoj ovih delatnosti su izuzetno skromna i kao takva iziskuju dug vremenski period da bi se, samo oslanjanjem na sopstvene snage, došlo do željenih rezultata. Zato su one, $\mathrm{u}$ procesu reindustrijalizacije nužno upućene na uvoz stranog kapitala $\mathrm{i}$ transfer tehnologija iz inostranstva.

\section{Konkurentnost industrije zemalja zapadnog Balkana u periodu tranzicije: merenje $\mathbf{i}$ analiza}

U osnovi brojnih definicija konkurentnosti jeste sposobnost zemlje da izvozi. Osim toga, ovaj pojam uključuje još i niz drugih činilaca kao što su: stepen uspešnosti nacionalne privrede u eksploataciji prirodnih, materijalnih i ljudskih resursa u proizvodnji i u nastupu na tržištu, produktivnost, životni standard stanovništva, bilateralne i multilateralne ugovore i sporazume kojih je zemlja potpisnica, članstvo zemlje u različitim međunarodnim organizacijama i slično (Božić Miljković, 2012:70). Politička i ekonomska prekretnica koju su sve zemlje zapadnog Balkana doživele '90-ih godina prošlog veka, dotakla je, u negativnom smislu, sve elemente njihove konkurentnosti. Kao što je napred opisano, krizom prelaska na sistem tržišne ekonomije najviše je bio pogođen sektor industrije. Pad konkurentnosti industrijskih proizvoda u ovoj grupi zemalja na početku je bio generisan političkom nestabilnošću, sankcijama, smanjenjem industrijske 
proizvodnje, orijentacijom na primarne proizvode kao glavne izvozne adute i sl. U kasnijim godinama tranzicije, faktori koji su imali ograničavajuće dejstvo na rast konkurentnosti u industriji bili su: nizak nivo ekonomskog razvoja, neizgrađenost institucija tržišne privrede, proces tranzicije koji predugo traje i sadržaj njihovih ekonomskih politika (Kittova \& Steinhauser, 2018: 57). Niska konkurentnost industrijske proizvodnje je, upravo zbog dugog perioda trajanja, postala odlika zapadnobalkanskih tranzicionih ekonomija. Poslednjih godina, te zemlje čine napore na planu unapređenja konkurentnosti i, premda na tom planu nema značajnijih pomaka, važno je konkurentnost meriti i na osnovu rezultata njome upravljati.

Jedan od kredibilnih pokazatelja koji služi za merenje i analizu konkurentnosti industrije je UNIDO Competitive Industrial Performance Index (UNIDO CIP index report 2020). Za merenje konkurentnosti, ovaj indeks uzima u obzir promene vrednosti produktivnosti koje se analiziraju praćenjem pet pokazatelja: indeks dodate vrednosti industrije per capita (MVApc), indeks učešća dodate vrednosti industrije u BDP-u (MVAsh), učešće srednjih I visokotehnoloških aktivnosti u ukupnoj dodatoj vrednosti industrije (MHVAsh), indeks intenziteta industrijalizacije (INDint), i indeks učešća dodate vrednosti svetske industrije (lmWMVA) (Andreoni, A, 2014: 3-5). Da bi merenje konkurentnosti bilo preciznije I potpunije, ovaj indeks uključuje i strukturne promene izvoznih performansi, koje se takođe analiziraju pomoću pet pokazatelja: indeks izvoza industrijskih proizvoda per capita (MXpc), učešće izvoza industrijskih proizvoda u ukupnom izvozu (MXsh), učešće proizvoda srednjih I visokoh tehnologija u ukupnom izvozu industrijskih proizvoda (MHXsh), indeks kvaliteta izvoza industrijskih proizvoda (MXQual) i indeks učešća u svetskom izvozu industrijskih proizvoda (lmWMT). Dobijene vrednosti CIP indeksa kreću se od 0 do 1 . Vrednosti bliže jedinici pokazuju da zemlja na koju se odnose ima veći nivo produktivnosti i veći intenzitet strukturnih promena, odnosno da je njena konkurentnost odraz rezultata ostvarenih u procesu industrijalizacije.

Tabela 3

UNIDO CIP index: rang i vrednosti ostvarene u zemljama zapadnog Balkana i odabranim bivšim socijalističkim zemljama u periodu od 2005. do 2020. godine

\begin{tabular}{|l|c|c|c|c|c|c|c|c|}
\hline & \multicolumn{2}{|c|}{2005.} & \multicolumn{2}{c|}{2010.} & \multicolumn{2}{c|}{2015.} & \multicolumn{2}{c|}{2020.} \\
\cline { 2 - 10 } & $\begin{array}{c}\text { rang } \\
(122)\end{array}$ & skor & $\begin{array}{c}\text { rang } \\
(133)\end{array}$ & skor & $\begin{array}{c}\text { rang } \\
(148)\end{array}$ & skor & $\begin{array}{c}\text { rang } \\
(152)\end{array}$ & skor \\
\hline Albanija & 77 & 0,13 & 94 & 0,01 & 106 & 0,01 & 118 & 0,01 \\
\hline BiH & 65 & 0,22 & 83 & 0,02 & 81 & 0,02 & 80 & 0,03 \\
\hline Makedonija & 66 & 0,15 & 84 & 0,02 & 78 & 0,03 & 77 & 0,03 \\
\hline Srbija &.. &.. & 76 & 0,03 & 62 & 0,04 & 62 & 0,04 \\
\hline Crna Gora &.. &.. & 121 & 0,01 & 122 & 0,01 & 127 & 0,01 \\
\hline \hline Bugarska & 63 & 0,05 & 59 & 0,05 & 54 & 0,05 & 54 & 0,05 \\
\hline Hrvatska & 56 & 0,06 & 55 & 0,06 & 53 & 0,06 & 57 & 0,05 \\
\hline
\end{tabular}




\begin{tabular}{|l|c|c|c|c|c|c|c|c|}
\hline Mađarska & 25 & 0,16 & 27 & 0,16 & 26 & 0,15 & 27 & 0,14 \\
\hline Poljska & 30 & 0,13 & 26 & 0,16 & 23 & 0,17 & 22 & 0,16 \\
\hline Rumunija & 38 & 0,10 & 36 & 0,11 & 37 & 0,10 & 31 & 0,10 \\
\hline
\end{tabular}

Izvor: https://stat.unido.org/database/CIP\%2020, pristupljeno novembra 2020.

Podaci prezentovani u tabeli potvrđuju da se sve zemlje zapadnog Balkana suočavaju sa problemom niske konkurentnosti, što znači da politika reindustrijalizacije ne daje željene rezultate. Prema vrednostima CIP indeksa, ova grupa zemalja je daleko iza ekonomski razvijenih zemalja zapadne Evrope, ali i od nekih bivših socijalističkih zemalja kao što su Rumunija, Poljska ili Mađarska. Odlika posmatranih bivših socijalističkih zemalja jeste da u čitavom posmatranom periodu pokazuju stabilne vrednosti indeksa industrijske proizvodnje, dok su kod zemalja zapadnog Balkana prisutna velika odstupanja naročito u periodu između 2005. i 2010. godine. Među posmatranim zemljama zapadnog Balkana, u indeksu industrijske konkurentnosti, blagu prednost ima Srbija, što je i opravdano, ako imamo u vidu da je ova zemlja u periodu od 2006. do 2016. godine imala najveći priliv stranih direktnih investicija. U skladu sa politikom reindustrijalizacije, deo investicija je plasiran u revitalizaciju postojećih i razvoj novih industrijskih kapaciteta: automobilsku industriju, industriju mašina i opreme i razne grane prerađivačke industrije. Na taj način je povećana produktivnost i sprovedena modernizacija tradicionalnih sektora industrije. Efekti investicija na privredni razvoj bi bili daleko veći da su ulaganja vršena u nove propulzivne sektore, odnosno da je usvojena i sprovedena strategija tzv. pametne specijalizacije (Jakopin, 2017: 171).

U narednoj tabeli data je uporedna analiza vrednosti pokazatelja koji ulaze u sastav kompozitnog CIP indeksa za zemlje zapadnog Balkana i odabrane bivše socijalističke zemlje.

Tabela 4

UNIDO CIP index analiza po komponentama: zemlje zapadnog Balkana, 2018. Godina

\begin{tabular}{|l|c|c|c|c|c|}
\hline & Albanija & BiH & $\begin{array}{c}\text { S. } \\
\text { Makedonija }\end{array}$ & Srbija & Crna Gora \\
\hline MVApc (USD) & 277 & 667 & 590 & 728 & 288 \\
\hline MVAsh (\%) & 0,17 & 0,34 & 0,32 & 0,44 & 0,10 \\
\hline MHVAsh (\%) & 0,06 & 0,22 & 0,37 & 0,32 & 0,18 \\
\hline INDint & 0,11 & 0,28 & 0,34 & 0.38 & 0,14 \\
\hline lmWMVA & 0,00 & 0,00 & 0,00 & 0,00 & 0,00 \\
\hline MXpc (USD) & 422 & 1.796 & 3.101 & 1.845 & 476 \\
\hline MXsh (\%) & 0,43 & 0,85 & 0,95 & 0,86 & 0,65 \\
\hline MHXsh (\%) & 0,05 & 0,30 & 0,69 & 0,50 & 0,29 \\
\hline
\end{tabular}




\begin{tabular}{|l|c|c|c|c|c|}
\hline MXQual & 0,24 & 0,57 & 0,83 & 0,68 & 0,47 \\
\hline lmWMT & 0,00 & 0,00 & 0,00 & 0,01 & 0,00 \\
\hline
\end{tabular}

Izvor: UNIDO Competitive Industrial Performance Report 2020.

Tabela 5

UNIDO CIP index analiza po komponentama:

odabrane bivše socijalističke zemlje, 2018. godina

\begin{tabular}{|l|c|c|c|c|c|}
\hline & Bugarska & Hrvatska & Mađarska & Poljska & Rumunija \\
\hline MVApc (USD) & 1.135 & 1.642 & 2.942 & 2.704 & 2.145 \\
\hline MVAsh (\%) & 0,40 & 0,35 & 0,58 & 0,53 & 0,57 \\
\hline MHVAsh (\%) & 0,38 & 0,34 & 0,71 & 0,42 & 0,57 \\
\hline INDint & 0,39 & 0,34 & 0,65 & 0,48 & 0,57 \\
\hline lmWMVA & 0,00 & 0,00 & 0,01 & 0,03 & 0,01 \\
\hline MXpc (USD) & 3.501 & 3.624 & 11.734 & 6.170 & 3.711 \\
\hline MXsh (\%) & 0,75 & 0,90 & 0,94 & 0,92 & 0,93 \\
\hline MHXsh (\%) & 0,50 & 0,51 & 0,84 & 0,60 & 0,69 \\
\hline MXQual & 0,62 & 0,70 & 0,89 & 0,76 & 0,81 \\
\hline lmWMT & 0,01 & 0,01 & 0,05 & 0,10 & 0,03 \\
\hline
\end{tabular}

Izvor: UNIDO Competitive Industrial Performance Report 2020.

Podaci pokazuju da su kapaciteti proizvodnje iskazani per capita $\mathrm{u}$ zemljama zapadnog Balkana višestruko manji nego u drugoj posmatranoj grupi zemalja. Najvišu vrednost manufacturing value added per capita index (MVApc) u grupi zapadnobalkanskih zemalja ima Srbija (728 USD), premda je to značajno niža vrednost od one koju ostvaruju druge evropske zemlje prikazane u tabeli 5. Vrednosti MVApc indeksa koje ostvaruju Albanija i Crna Gora, svrstavaju ove dve zemlje u red zemalja u razvoju. Slična je situacija i kod indeksa koji opisuje izvoz prerađivačke industrije per capita (MXpc) gde najvišu vrednost ima Makedonija (3.101 USD), a najniže opet Albanija i Crna Gora. U pogledu intenziteta industrijalizacije (INDint), zemlje zapadnog Balkana su u rangu sa Hrvatskom i Bugarskom, ali ispod nivoa koji imaju Mađarska, Poljska i Rumunija. Kao zemlje sa izuzetno niskim intenzitetom industrijalizacije izdvajaju se Albanija, Bosna i Hercegovina i Crna Gora. Ove tri zemlje su u proces reindustrijalizacije ušle tek sredinom prve decenije XXI veka i kod njih je on sproveden u mnogo manjem obimu nego u Srbiji i Makedoniji. Geografski položaj ovih zemalja koji omogućava izlaz na more ili pruža potencijale za razvoj zimskog planinskog turizma, opredelio je ove zemlje da svoj privredni razvoj zasnivaju na razvoju sektora turističkih i drugih usluga, više nego na razvoju industrije. One nisu ostale izvan procesa reindustrijalizacije, ali su razvojni efekti tog procesa, upravo zahvaljujući razvojnoj orijentaciji koja se zasniva na geografskom položaju i komparativnim prednostima koji iz tog položaja proizilaze, bili mnogo manji nego u Srbiji, Makedoniji i dru- 
gim posmatranim zemljama. Interesantna je činjenica da industrial export quality index (MXQual), ne pokazuje značajna odstupanja u posmatrane dve grupe zemalja. Industrijski proizvodi koji su svojstveni obema grupama zemalja i koji dominiraju u njihovom izvozu su: mašine I transportna sredstva, proizvodi za auto-industriju, prerađeni poljoprivredni proizvodi, piće I duvan, hemijski proizvodi, građevinski material i sl.

Veći rast UNIDO CIP indeksa kao pokazatelja međunarodne konkurentnosti industrijskih proizvoda zemlje zapadnog Balkana ne mogu ostvariti za kratko vreme, bez ozbiljnih strukturnih reformi i što je najvažnije bez daljeg sprovođenja politike reindustrijalizacije i velikih investicija u industriju. Snažna i konkurentna industrija za zemlje zapadnog Balkana ima mnogo širi ekonomski značaj od unapređenja strukture njihove izvozne ponude, povećanja konkurentnosti i obima njihovog izvoza. Razvijena industrija, posebno ako se njen rast finansira iz sredstava domaće akumulacije, znači veći stepen ekonomske samostalnosti i bolje pozicije u međunarodnim ekonomskim odnosima, što je za zemlje zapadnog Balkana sa aspekta njihovog uključivanja u evrointegracije od izuzetnog značaja.

\section{ZAKLJUČAK}

Proces reindustrijalizacije u zemljama zapadnog Balkana predstavlja ključnu determinantu njihovog budućeg ekonomskog razvoja i njihovog položaja u međunarodnim ekonomskim odnosima. Politika i strategija ponovnog industrijskog razvoja od početka ovog veka do danas nisu dale zapažene rezultate. U tom periodu nije došlo do značajnijih promena u veličinama njihovih nacionalnih industrija, njihovom položaju u evropskom i regionalnom ekonomskom okruženju, niti su uočeni pozitivni efekti reindustrijalizacije na povećanje konkurentnosti proizvodnje i izvoza industrijskih proizvoda. Po razvoju industrije i konkurentnosti koju ostvaruju na međunarodnom tržištu, zemlje zapadnog Balkana su u inferiornijem položaju u odnosu na grupu odabranih bivših socijalističkih zemalja, koje su danas članice Evropske unije.

Analizom konkurentnosti korišćenjem UNIDO metodologije: CIP indeksa i pod-indeksa koji daju konačni rezultat konkurentnosti, u slučaju zemalja zapadnog Balkana i grupe bivših socijalističkih zemalja, dolazimo do zaključka da konkurentnost predstavlja „slabu tačku“ svih zemalja zapadnog Balkana. Niske vrednosti manufacturing value added per capita index (MVApc) i CIP indeksa pokazuju pozitivnu korelaciju između niskog nivoa privrednog razvoja i niskog nivoa konkurentnosti, dok niske vrednosti manufacturing export per capita index (MXpc) i CIP indeksa govore o odsustvu ekonomski podsticajnih strukturnih promena.

Usled nedostatka sopstvene akumulacije, zemlje zapadnog Balkana su prinuđene da razvoj svojih industrija temelje na prilivu stranih direktnih investicija. Na tom polju je zemljama zapadnog Balkana važno da budu konkurentne u odnosu na zemlje iz okruženja koje takođe imaju velike potrebe za stranim kapitalom. Velike apsorbcione mogućnosti koje zapadni Balkan ima za stranim kapitalom limitirane su nizom objektivnih činilaca koji su nastali kao posledica i prateći efekat dosadašnjeg procesa 
tranzicije. Neki od često pominjanih činilaca su: odsustvo vladavine prava, neefikasno sudstvo, korupcija, neefikasna administracija, nedostatak kvalifikovane radne snage i sl. Svi ovi faktori negativno utiču na razvoj biznisa i posebno limitiraju ulazak preko potrebnih greenfield investicija na ovaj deo evropskog tržišta. Negativne efekte deindustrijalizacije nije moguće poništiti, ali je, koncipiranjem kredibilne industrijske politike i njenim doslednim sprovođenjem, moguće načiniti pomak i procesom reindustrijalizacije upravljati na kvalitetniji i prosperitetniji način.

\section{LITERATURA}

Andreoni, Antonio. "Structural Learning: Embedding discoveries and the dynamics of production". Structural Change and Economic Dynamics 29 (2014): 58-74.

Božić Miljković, Ivana. "Konkurentnost balkanskih zemalja". Međunarodni problemi 1 (2012): 67-81.

Božić Miljković, Ivana. Ekonomije balkanskih zemalja na početku XXI veka. Beograd: Institut za međunarodnu politiku i privredu, 2018.

Božić, Milorad. "Ekonomske funkcije države - dometi i ograničenja". Zbornik radova Pravnog fakulteta u Nišu 34-35 (1994-1995) (1996): 15-29.

Božić, Milorad. "Deindustrijalizacija zemalja u tranziciji i njene ekonomske poskedice". Teme 2, 33 (2009): 423-442.

Čobeljić, Nikola. Privreda Jugoslavije. Beograd: Savremena administracija, 1978.

Đukić, Petar. "Reindustrijalizacija po meri politike - šansa i rizik". U Deindustrijalizacija u Srbiji: Mogućnosti revitalizacije industrijskog sektora, ur. Božo Drašković, 84-106. Beograd: Institut ekonomskih nauka i Beogradska bankarska akademija, 2014.

Elke Dall \& Ines Marinković (2014). "The Steering Platform on Research for the Western Balkan: History and Outlook". In $R \& D$ and Innovation in Western Balkans Moving Towards 2020, edited by Ines Marinkovic and Elke Dall, 43-47. Centre for Social Innovation, ZSI Austria.

Estrin, S, Uvalić, M. "Foreign Direct Investment in the Western Balkans: What Role Has it Played During Transition?". Comparative Economic Studies 58, 3 (2016): 455-483.

Jakopin, Edvard. "Smart specialisation of manufacturing industry: Relying on one's own strengths and targeted attraction of FDI". Ekonomika preduzeća 65, 1-2 (2017): 155-173.

Jugoslavija 1945-1985, statistički prikaz. Beograd: Savezni zavod za statistiku, 1986.

Kittova, Zuzana \& Dusan Steinhauser. "The International Economic Position of Western Balkan Countries in Light of their European Integration Ambitions". Journal of Competitiveness 10, 3 (2018): 51-68. 
Kovačević, Mlađen. "Dimenzije i uzroci neuspešne tranzicije zemalja Zapadnog Balkana, a posebno Srbije". Balkan magazin (www. balkanmagazin.net, sreda, 08. jun 2011, pp. 14-34).

Mićić, Vladimir. "Ponovna industrijalizacija i strukturne promene u funkciji ekonomskog razvoja Republike Srbije". Ekonomski horizonti 17, 1 (2015): $15-31$.

Przywara, Rainer. "Deindustrialization - Opportunity or Threat?". Athens Journal of Business \& Economics 3, 4 (2017): 427-462.

Radošević, Slavo (2014) “Technology Upgrading and RTD Challenges in Western Balkan Region: Issues and Policy Options". In R\&D and Innovation in Western Balkans Moving Towards 2020, edited by Ines Marinkovic and Elke Dall, 59-65. Centre for Social Innovation, ZSI Austria.

Sanfey Peter and Jakov Milatović. "The Western Balkans Regional Economic Area: From Economic Cooperation to Economic Integration". In Western Balkan Economies in Transition - Recent Economic and Social Developments, edited by Osbild Reiner \& Bartlett Will. Springer International Publishing, 2019.

Savić, Ljubodrag. "Reindustrijalizacija kao osnova novog modela razvoja". U Ekonomsko-socijalna struktura Srbije - učinak prve decenije tranzicije. Beograd: NDE, AEN I Ekonomski fakultet, 2010.

UNCTAD Handbook of Statistics; http://unctadstat.unctad.org

UNIDO; https://stat.unido.org

Vukmirica Vujo. Kapital i socijalizam. Beograd: Naučna knjiga, 1988.

World Bank Group (2018). Redovni ekonomski izveštaj 14 Viši ali krhki rast. http://pubdocs.worldbank.org/en/536081538630265238/WBRER14-webSRB.pdf dostupno: 10/2020.

World Bank; https://databank.worldbank.org

World Bank; Yugoslavia and the World Bank, September 1979; http:// documents 1.worldbank.org/curated/en/717881468759857058/pdf/multipage.pdf 


\title{
CONSEQUENCES OF DEINDUSTRIALIZATION AND ECONOMIC EFFECTS OF REINDUSTRIALIZATION IN THE EXAMPLE OF THE WESTERN BALKAN COUNTRIES
}

\begin{abstract}
Summary
Reindustrialization is a process of renewing industrial production with the aim of increasing the participation of industry in the creation of total GDP. In the Western Balkan countries, reindustrialization has been recognized as a necessary process whose goal is to increase employment, improve the export structure and the position in international economic relations. Reindustrialization is, as an economyimproving concept, determined by the very essence of the transition process and the reforms that have marked that process. In other words, reindustrialization is an "answer" to the negative consequences of deindustrialization and economy tertiarization. The application of these two concepts to the economies of the Western Balkan countries, thanks to their economic heritage and geoeconomic position, has yielded no positive effects as was the case in some other countries in transition. This paper deals with the analysis of the effects of the process of reindustrialization in the Western Balkan countries thus far, with a particular emphasis on the potentials and possible directions of the development of their industries in the future.
\end{abstract}

Keywords: deindustrialization, reindustrialization, economy, Western Balkans. 